\title{
STUDENTS' INTERACTION IN ONLINE CLASSES DURING COVID 19 PANDEMIC IN NORTH MACEDONIA
}

\author{
Brikena Xhaferi, South East European University, North Macedonia, \\ b.xhaferi@seeu.edu.mk
}

Gëzim Xhaferri, North Macedonia, b.xhaferi@seeu.edu.mk, g.xhaferi@seeu.edu.mk

Original scientific paper

DOI: 10.31902/fll.36.2021.19

\begin{abstract}
The purpose of this paper was to analyze students' interaction activities used in online classes during the COVID-19 Pandemic. The notion of interaction is widely recognized in the field of second language acquisition following Long's interaction hypothesis (1985) which states that language proficiency is highly increased if there is an interaction in the FL classroom. For interaction in online classes teachers need to encourage high student interactivity and create a supportive and friendly environment and the first step toward achieving this would be provide a syllabus that clearly and simply describes expectations for the course in general and notes specific guidelines for each assignment, instructions, and deadlines (Durrington et al., 2006).

Therefore, this issue remains challenging for teachers who are expected to convert their classroom teaching into an online platform, thus, maintaining the students' interaction as the central element in teaching. Without any doubts, this task requires additional time, preparation, and technical support. Adequate staff development and student motivation are critical to ensure that faculty can design online courses effectively and develop the skills in enhancing students' interaction. The research instruments used for this study are students' questionnaires, students' reflections and classroom observations of online teaching. The study was conducted at South East European University (SEEU) in North Macedonia with 80 students majoring in English Language and Literature as well as 5 EFL teachers.

The results of the study showed that students perceived interaction as a very important element of the qualitative teaching and have given useful suggestions for teachers to increase their engagement in interaction activities. Given the restrictions of online teaching, in all online classes observed, exemplary interaction was achieved through Question and Answer method Comprehension technique and Discussion and Analysis of Online Videos where the students interacted with the teacher and their peers.
\end{abstract}

Keywords: online teaching, interaction, university students, COVID-19 Pandemic 


\section{Introduction}

When the COVID-19 virus spread around the world, many schools and other educational institutions in the world switched from face-to-face teaching environments to virtual classes. At first, this type of teaching seemed to be complicated and scary for teachers and students. The newly created situation with pandemic was nor predicted neither by common individuals nor by world leading scientists in the field of virology. Even the best universities in the world began teaching online in order to prevent new infections. For developed countries, this was not a huge problem due to technology tools and trained staff members they have, but for many poor countries this was seen as a difficulty in continuing with their teaching. In different environments, students do not have "reliable internet access and/or technology and they struggle to participate in digital learning; this gap is seen across countries and between income brackets within countries... whilst $95 \%$ of students in Switzerland, Norway, and Austria have a computer to use for their schoolwork, only 34\% in Indonesia do". (The World Economic Forum COVID Action Platform, 2020, NP cited in Xhaferi and Xhaferi, 2020, p.88). This shows that online teaching environment can lead to a failure of the education system in many countries.

The research context of this study was South East European University (SEEU) in Tetovo, North Macedonia. This University used Elearning platforms before the spread of the COVID-19 pandemic in the world. The main mission of this University was to support students' learning, a digital native generation, with a hybrid approach to learning using different E-learning platforms such as: ANGEL, LIBRI, and most recently Google Classroom. However, due to COVID-19 pandemic, this mode of teaching was shifted to a complete online teaching mode using Google Meet as an extension of Google Classroom. For teachers and students of SEEU this was a challenging year despite the fact that staff members regularly attend professional development workshops on the use of new technologies in teaching. All teachers used Google Classroom to upload course materials (syllabus, handouts) post course announcements, create quizzes and other assignments and also create discussion forums for students. In short, the shift to online teaching was not a surprise for us, yet it had several challenges which will be discussed in the paper.

\section{Literature review}

Since the COVID-19 Pandemic has changed the way of teaching from onsite to online, professors are required to cope with this situation 
and provide their students with quality teaching. The concern for success of their everyday instruction, forced educators and researchers around the globe to focus their studies on the most important elements in teaching. Classroom interaction and activities which motivates the students to be engaged in classes are believed to be the main ingredients of qualitative teaching and learning outcomes.

The positive role that interaction has on Second Language Acquisition is explained by Stephan Krashen (1988) and his Hypothesis. According to Krashen (1988) the process of acquisition involves meaningful interaction in the target language that is natural communication where speakers are focused more in the messages they convey rather than in the form of their utterances.

This leads us to rethink our teaching practices and offer more communicative opportunities for the students. Creating an online learning setting which will encourage students to interact more with their peers, teachers and content can result in improved motivational, cognitive, and affective outcomes (Croxton, 2014 cited in Zhang and Lin, 2019, p.4). In this regard, (Davis \& Roblyer (2005 cited in Zhang and Lin, 2019, p.4) pointed out that: "Online learning requires the teacher to be well versed in the relevant instructional practices, virtual management techniques, and approaches that effectively engage students." Professors' role in this aspect is crucial because they are responsible to initiate and encourage class discussion and interaction.

There are several elements important for classroom interaction. Chickering and Gamson (1987 cited in Grandzol and Grandzol, 2010) are of the opinion that several principles are directly related to interaction among the participants of the learning process. They are: contacts between students and faculty; reciprocity and cooperation among students; prompt feedback; the timing for tasks and communication of high expectations.

\section{Online interaction elements}

When it comes to interaction in online environment, Cavanaugh et.al (2008) claimed that " interaction... infers that students are closely connected to their teachers. When this occurs on a one-on-one basis, it enables more individualized attention than is actually possible in the traditional classroom. Therefore, an effective teacher can be identified by the ability to make individual connections with students". According to them, teachers in online learning have multiple roles such as motivator, a guide, a mentor, and a listener to their students. Krishnamurthi (2000) believes that "One of the most difficult aspects of teaching online is integrating student - teacher interactions similar to a 
face-to-face course in an online course. The multisensory, multimodal, multitasking interactions that are common place in a face-to-face course are difficult to capture or emulate in an online course.

Robertson and Klotz (2002) pointed out that " that the literature provides evidence that online courses are often configured and delivered in a style more often associated with independent study and that, while this format might work in some instances, it leaves what they term a 'missing link' in student learning "(cited in Downing et.al,2016). They also suggested "that students in an online learning environment lack the opportunity to experience the benefits of both structured dialogue and a sense of community that can be created in a traditional on-site classroom environment "(p.3). Another different aspect of the learners was suggested by Downing \& Chim (2004a) who investigated the relationship between personality type and different learning environments, "suggesting that classroom-based 'introverts' behave more like 'extraverts' when involved in online discussion forums and are more active in online discussions than when based in the classroom"(p.3).

Taking into consideration the different facts provided by the scholars, investigating interaction in online classes is very important in the context of North Macedonia the COVID-19 Pandemic. Therefore, this study can be considered a pioneer study on how interaction is perceived by EFL learners and some techniques which can be used by teachers to improve it. The results of this study will be valuable for teachers in the country and beyond.

One study relevant to the present study was conducted in Turkey. Kaymak and Horzum (2013) conducted a study with 320 students enrolled in online learning of post-graduate programs in Sakarya University, Turkey. The research instrument used was a survey sent to the participants and the aim of the research was to investigate if there was any relationship between students' readiness for online learning and their perceived structure and interaction. The results showed that there was a positive relationship between students' readiness for online learning and perceived interaction, but negative relationship was found between structure and readiness or online learning and interaction.

Another study was carried out by Grandzol and Grandzol in 2010. The main aim of their study was to analyze interaction in online courses using the course management system which measured the time students interacted. The sample of the study included 359 lower-level online, undergraduate business courses and the data collection method lasted for two years in business courses at six Mid-western community colleges in the USA. The results from the data collected showed that 
there was no connection between course completion and either class size or students' interaction with faculty. Furthermore, it was discovered that student-student interaction was associated with completion rates in a negative way. Despite contradictory findings from earlier studies, the researchers concluded that the more students interact with each other, the less likely they are to complete the course.

\section{Research methodology}

The present study was conducted during the Fall semester 2020/2021 at SEEU. An online questionnaire was sent to the students in order to find out their opinions related to interaction during the online classes. Also, the students' reflections were used to identify students' satisfaction with online classes as well as their difficulties when it comes to their engagement and interaction in the classes taken at the English Department of SEEU. There were 80 participants from first, second, third and fourth year students of both genders and different ethnicities, Albanian, Macedonia, Turkish and Roma. Also, 5 teachers of EFL were observed teaching online using a video-communication service Google Meet.

In this study, the following research questions were addressed:

1. What are students' opinions about interaction during the online classes?

2. How are the students satisfied with the kind of activities the teacher varied during the online lessons and what do they prefer to have?

3. Which activities do the teachers use in order to accomplish interaction in online classes?

The research procedure started with the online students' questionnaire which was completed by 80 students of the Department of the English Language and Literature. The participants were explained the purpose of this study and they were asked to help the researcher by giving honest answers. In the second phase of the study, a sample of 12 students were selected from the total sample of 80 and were instructed to write a reflection paper related variety of activities teachers used to ensure the interaction is achieved in the best possible ways. Finally, 5 classroom observations were conducted to closely see which activities are used to accomplish interaction during online teaching.

\section{RESULTS}

\section{Students' questionnaire}

The online questionnaire was sent to the participants of the study in order to find out their opinions and experiences in online classes at 
the Department of English Language and Literature at SEEU during the pandemic. The questionnaire contains 20 items and the Likert scale with five options was used for students' responses. The last question of the questionnaire was an open-ended question where the participants were asked to write down some practical suggestions which can help teachers improve interaction in the class.

\begin{tabular}{|c|c|c|c|c|c|}
\hline & SD & $\mathrm{D}$ & $\mathrm{N}$ & A & SA \\
\hline $\begin{array}{l}\text { 1. The online teaching helped me develop intellectual } \\
\text { skills (critical thinking, analytical reasoning) }\end{array}$ & - & $10 \%$ & $10 \%$ & $25 \%$ & $55 \%$ \\
\hline $\begin{array}{l}\text { 2. The graded assignments were meaningful and } \\
\text { helped me apply the concepts taught in the course }\end{array}$ & & & $20 \%$ & $55 \%$ & $35 \%$ \\
\hline $\begin{array}{l}\text { 3. The learning material was engaging and intellectually } \\
\text { stimulating. }\end{array}$ & $10 \%$ & $15 \%$ & $15 \%$ & $35 \%$ & $25 \%$ \\
\hline $\begin{array}{l}\text { 4. The instructor provided useful feedback on my } \\
\text { assignments. }\end{array}$ & - & - & $5 \%$ & $55 \%$ & $40 \%$ \\
\hline 5. This course was satisfying for me & $15 \%$ & $10 \%$ & $20 \%$ & $25 \%$ & $30 \%$ \\
\hline 6. The course developed my communicative skills & $10 \%$ & - & $20 \%$ & $45 \%$ & $25 \%$ \\
\hline 7. The activities were interactive and motivational & & $15 \%$ & $25 \%$ & $35 \%$ & $25 \%$ \\
\hline 8. The teacher asked us a lot of questions & $15 \%$ & $10 \%$ & $20 \%$ & $40 \%$ & $15 \%$ \\
\hline \multicolumn{6}{|l|}{ 9.I was encouraged to interact with our peers } \\
\hline 10. I was motivated to study in online environment & $20 \%$ & $20 \%$ & $10 \%$ & $25 \%$ & $25 \%$ \\
\hline
\end{tabular}

Table 1: Questionnaire results (questions 1-10)

Table 1 shows the data obtained from the students' responses (expressed in percentages) given by selecting one out of five choices, Strongly disagree, Disagree, Neutral, Agree and Strongly Agree. Students' perceptions of online teaching were revealed in many statements. The results show that online teaching was very helpful in developing students' critical skills and analytical reasoning (55\%) and the participants were satisfied with teachers' feedback on their assignments (40\%). Feedback is powerful to support students' learning; therefore, this should be done on regular basis. Similarly, the participants expressed that the graded assignments were meaningful and helped them to utilize the concepts they learned in online classes (35\%) and the participants were generally satisfied with the course $(30 \%)$, while communication skills and motivational activities were used to some extend by the teachers (25\%). Despite the fact the Question-and-Answer technique is very powerful, and the teacher can keep students engaged, the participants indicated that it is not used often by the teacher (14\%).

According to the results in Table 2, it seems the statements $(13,17$ and 20) have received the highest percentage. The participants' opinion is that they like to interact with their classmates (45\%), and they strongly believe that they must interact to achieve higher grades (40\%). Also, the participants believe that interactions help them to be better users of 
English language (40\%). When it comes to the use of classroom activities, the participants expressed that the teachers used variety of them (30\%) and that teachers were highly prepared to teach online (35\%). Even though, interaction is highly appreciated by the participants, $35 \%$ of the participants preferred to work individually. This depends on students' learning style and personality trait, such as extroversion and introversion.

11. The online classes were challenging for us

$\begin{array}{ccccc}\text { SD } & \text { D } & \text { N } & \text { A } & \text { SA } \\ 35 \% & 35 \% & 10 \% & 10 \% & 10 \% \\ & & & & \\ 15 \% & 15 \% & 20 \% & 20 \% & 20 \% \\ 5 \% & 10 \% & - & 40 \% & 45 \% \\ & & & & \\ 20 \% & 25 \% & - & 35 \% & 20 \% \\ 30 \% & 20 \% & - & 20 \% & 30 \% \\ - & - & 15 \% & 50 \% & 35 \% \\ - & 10 \% & 10 \% & 40 \% & 40 \% \\ & & & & \\ 15 \% & 15 \% & 10 \% & 25 \% & 35 \% \\ & & & & \\ 25 \% & 20 \% & 15 \% & 25 \% & 20 \% \\ 10 \% & - & 10 \% & 40 \% & 40 \%\end{array}$

12. The online materials used by the teachers promoted development of all language skills

13. I like to interact with my classmates during classes

14. I prefer to work together in online tasks given by the Teacher

15. I learn better individually

16. Teachers were highly prepared for online teaching

17. I must interact because class participation is an important element of assessment

18. Different activities were used with us during online classes

19. I think that Internet has positive impact on interaction

20. I believe that interaction helps us to be better in English

Table 2: Questionnaire results (questions 11-20)

\section{Open-ended question results}

The study participants were asked to suggest some techniques that teachers can incorporate in their classes. The following are some of the responses.

Table 3 summarizes the participants' responses who provided some practical suggestions which might help teachers to incorporate them in their classes in order to increase student interaction. Students revealed that they would prefer to be asked questions by the teachers when they lecture (7 similar responses). It seems that students want to be involved in the classes all the time. Then, we have received 5 similar suggestions for teachers and that is to use a mix of learning tools, more visuals and audio and provide feedback. Also, the participants felt that teachers should appoint the students to answer the questions not only on voluntary basis but also everyone will be concentrated during the lesson. 3 similar suggestions were given for the cameras: they should be turned on and this could lead to a great interaction, and students would be obliged to interact instead just joining the Google Meet and teachers should set up simple/appropriate case scenarios which encourage problem solving and critical thinking activities in the class. These 
suggestions are very practical and can be applied by teachers without any difficulty.

\begin{tabular}{|l|l|}
\hline $\begin{array}{l}\text { Suggestions } \\
\text { for teachers to } \\
\text { increase }\end{array}$ & $\begin{array}{l}\text { Summary of students' responses } \\
\text { interaction' }\end{array}$ \\
\hline Ask questions in the lecture /ppt presentation \\
that can increase students' participation (7 \\
similar responses) \\
Use a mix of learning tools, more visuals and \\
audio and provide feedback (5 similar \\
responses) \\
Appoint the students to answer the questions \\
not only on voluntary basis (4 similar \\
responses) \\
The cameras should be turned on, and this \\
should lead to a great interaction because \\
every student would be obliged to interact \\
instead of just joining the Google Meet (3 \\
similar responses) \\
The classroom atmosphere should be \\
positive, and this would encourage interaction \\
among students \\
(3 similar responses) \\
Ask students to show and present their ideas, \\
presentations, video links, and encourage \\
discussions (2 similar responses) \\
Variety of shorter, quicker exercises so that \\
students don't have to spend as much time \\
answering (2 similar responses) \\
Posting discussion boards or questions on \\
Google Classroom for students to answer (1 \\
response) \\
Make the students feel more comfortable, \\
let's say quizzes like Kahoot would be helpful \\
(1 response)-
\end{tabular}

Table 3: Students' responses to the open-ended question 


\section{ANALYSIS OF THE REFLECTION PAPERS}

The analysis of the students' reflections shed light on students' satisfaction with the online teaching and their engagement in interaction during classes. There were 12 reflections out of which 4 were presented in the paper. They were prompted with some questions such as: "What are your overall impressions of online teaching", "What do you think about interaction opportunities that your are given by the teachers?", and "What do your teachers do to encourage student interaction during online classes?'. The following are some excerpts taken from the students' reflections.

\section{Reflection 1 (First year student)}

On March 11th 2020, an email was sent to the entire academic staff including students, announcing that the government had decided we would be off for two weeks with lectures because the early infected individuals with COVID-19 were detected. At the beginning, we were shocked and hoped that things will get to normality after two weeks. However, we did not only follow the entire semester via online applications, but we also were not allowed to take the exams at SEEU's campus classes.

For me, interaction is a vast component and a very important ingredient of a qualitative constructed curriculum, however, I consider it not very complicated to be applied in the online teaching system. The reason is that the teacher can create numerous criteria and penalties which might influence students' performance either with a positive or negative attitude.

The three main factors that impact students' interaction during online learning-teaching is listening to the instructions provided, speaking to participate and writing as in follow-up tasks. I would say that teachers together with students have managed quite well to provide and create another form of teaching that was not introduced and made common to educational systems around the world before.

\section{Reflection 2 (second year student)}

Online studies proved to be interesting with its own positive and negative sides. The positives were that we the students felt more comfortable now that we were at home, a place that we typically associate with safety, unlike the classroom in which we may become more stressed and nervous. Another positive aspect was that we could use our computers for research while in the classroom we would use our phones, which may not work due to the wi-fi capacity of the school. 
For me interaction is a very important part of learning and the teachers used different methods to make us participate in the classes. It is sometimes just questions and answers, sometimes presentations and the feedback in the end and often the teachers engaged in different activities and then we have to read our responses. The most motivated students always raise their hand to respond to teachers' questions but those most introverted ones need to be called upon so they can participate. Generally, it is going well with a few obstacles.

Problems occurred when the Internet connection was having troubles, or if there was a blackout. The students may also not pay so much attention and even leave their rooms to do something else since the teacher couldn't see their face. And while it may have been comfortable to have classes from home, there is also the chance that we may not focus so much while in such a comfortable setting. Using computers for cheating is also a problem and this should be prevented.

\section{Reflection 3 (third year student)}

Students' interaction during online classes

The interaction during our online classes was of course a lot different from face-to-face learning. However, I was pleasantly satisfied with most of the professors' approaches regarding this matter. Most of the teachers encouraged us to participate by calling out our names during discussions. In my opinion, this was a great method due to the fact that in face-to-face learning you can raise a hand and you feel more comfortable in participating, but in online classes, it can be difficult to concentrate and follow the lecture. When professors called out my name, I felt acknowledged and wanted to share my answers or opinion on the topic we were discussing. The activities that had videos, quizzes, and questions at the end or during made it easier for me to follow the lecture and I could remember the material better.

The level of motivation was certainly lower because you are at the comfort of your home and can follow the lesson from bed or a comfortable chair. Also, you don't have to wake up that early since there is no need to travel to the university. That had pros and cons because I got more sleep, but it took me a long time to concentrate during the starting 20 minutes of the first lecture. However, if you establish a routine and avoid the bed, sit at a desk or table, and pretend that you are in class, it can be almost as if you are actually there. At least that worked for me.

One suggestion that I think professors should consider is calling out students by their names. The option "raise your hand" on Google classroom that they added recently is excellent for this reason, but even 
if no one is raising their hand, calling out students by their name will motivate them to follow the lesson actively and get rid of the fear to share their thoughts. Also, if teachers are presenting the topic and talk with no pauses or without asking students to participate it is easy for us to lose focus and our thoughts can wander off.

\section{Reflection 4: (student of $3+1$ year)}

From my point of view, the university did an amazing job switching to online learning. If I am not mistaken, this was done within just few days. I think the university was able to adjust quickly due to the amazing technical team. The studies are structured much better than I expected. I don't really see a difference between the online and offline structures. The students were encouraged by professors to participate individually with activities such as: answering the questions that are asked by the professor, working on assignments and essays and also students were asked to give presentations. The professors knew how to use the different tools accordingly and the classes were, therefore, interactive and pleasant to attend.

Some of the exams had to be done in a written form. The camera was switched on the whole time so that the professor could see what we were doing. I think it was fair. I am generally good with IT skills; therefore, it was very helpful for me to receive clear instructions on what to do. The only suggestion that I have for my teachers is to involve all students and call them by name. In this case the classroom interaction will increase and we will learn more from each other.

Analyzing the samples of students' reflections on classroom interaction and online teaching, it can be seen that teachers use different activities which can promote online interaction. The most-used activities reported were: questions and answers, presentations and students' feedback, comprehension questions, different assignments and essays, discussion and analysis of different videos, and quizzes. The reflections revealed that students prefer to be called out by names in order for them to share their answers or their opinion with the class.

\section{DISCUSSION OF CLASSROOM OBSERVATIONS}

During phase 3 of the research, there were 5 observations conducted with teachers during online teaching. The researchers used a specific observation sheet (See Appendix 1) which focused on interaction activities used by different teachers in order to accomplish interaction in online classes. In addition, online observations were a good way to help the researchers see how teaching has changed in 
comparison to face-to-face learning and how do the teachers managed to make their teaching interactive in online conditions.

\begin{tabular}{|c|c|c|c|c|}
\hline 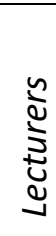 & $\begin{array}{l}\text { Interactive } \\
\text { activities at the } \\
\text { begging of the } \\
\text { class }\end{array}$ & $\begin{array}{l}\text { Interactive } \\
\text { activities } \\
\text { at the end } \\
\text { of the } \\
\text { class }\end{array}$ & $\begin{array}{l}\text { Interactive } \\
\text { activities } \\
\text { during the } \\
\text { class }\end{array}$ & $\begin{array}{l}\text { Student- } \\
\text { student } \\
\text { interaction } \\
\text { activities }\end{array}$ \\
\hline $\mathrm{L} 1$ & $\begin{array}{l}\text { Brainstorming } \\
\text { questions }\end{array}$ & $\begin{array}{l}\text { Question } \\
\text { and } \\
\text { answer } \\
\text { method }\end{array}$ & & $\begin{array}{l}\text { Students' } \\
\text { presentations } \\
\text { feedback }\end{array}$ \\
\hline $\mathrm{L} 2$ & $\begin{array}{l}\text { Question and } \\
\text { answer method }\end{array}$ & $\begin{array}{l}\text { Online } \\
\text { quiz }\end{array}$ & $\begin{array}{l}\text { Discussion } \\
\text { and } \\
\text { analysis of } \\
\text { the Online } \\
\text { Video }\end{array}$ & \\
\hline L3 & $\begin{array}{l}\text { Comprehension } \\
\text { questions }\end{array}$ & $\begin{array}{l}\text { Question } \\
\text { and } \\
\text { answer } \\
\text { method }\end{array}$ & & $\begin{array}{l}\text { Students' } \\
\text { assignments }\end{array}$ \\
\hline L4 & $\begin{array}{l}\text { Review of the } \\
\text { previous lesson }\end{array}$ & $\begin{array}{l}\text { Student } \\
\text { feedback } \\
\text { on the } \\
\text { lessons }\end{array}$ & $\begin{array}{l}\text { Discussion } \\
\text { and } \\
\text { analysis of } \\
\text { the Online } \\
\text { Video }\end{array}$ & $\begin{array}{l}\text { Students' } \\
\text { presentations } \\
\text { feedback }\end{array}$ \\
\hline L5 & $\begin{array}{l}\text { Comprehension } \\
\text { questions }\end{array}$ & $\begin{array}{l}\text { Question } \\
\text { and } \\
\text { answer } \\
\text { method }\end{array}$ & $\begin{array}{l}\text { Discussion } \\
\text { of online } \\
\text { reading } \\
\text { article }\end{array}$ & \\
\hline
\end{tabular}

Table 4: Interactive activities observed

Analyzing Table 4, we can see that the most-used interactive activity was Question and answer method were the students were asked by the lecturers to respond to the questions related to the lesson. In this regard, it is worth to emphasize that teachers also, provided feedback to student responses. Whenever, the student gave an incorrect answer, the lecturers redirected the students to the correct answer (in 3 cases observed) or help the students to provide the correct answer (in one case, L5).

Regarding the second-most used interactive activity used by the teachers was Discussion and analysis of the Online Video as used by 3 
lecturers. This method is completely new and applied in online environment with the aim to develop and strengthen students' critical thinking skills. The videos chosen were relevant to the lesson and they were always used during the lesson to engage students in learning. After they watched the video, they analyzed and discussed them with their peers and the student-student interaction was high during this activity.

Then, two other activities used by two lectures at different stages of learning. Namely, Comprehension questions were used by two lecturers at the beginning of the class and they aimed to clarify some concepts to the students.

Students' online presentations were also a new Method used during online teaching because previously the students gave their presentations in the class. Two lecturers used online presentations and the students were free to choose their topic which was related to the course syllabus. After a presentation, there was a ten minute feedback sessions were the students discussed the most important aspect of the presentations and also there were always questions for the presenters.

Finally, A review of the previous lesson and Brainstorming activities were used by one lecturer at the begging of the online class. Both these methods were applicable in face-to-face teaching but are easily used in the online environment as well. Also, Students' feedback to the lesson was not something new but it is certainly helpful for teachers to revise and reflect on their teaching.

In conclusion, it can be stated that generally students have positive experiences with online learning and the negative sides of it mentioned were the internet connection and not socializing with their classmates. It is known that socialization at the University is very important for students because it is the process which begins in childhood at home with one's family and continues in all levels of education. In this way students become more mature and more responsible for their actions.

When it comes to interaction in online classes, the students have listed several activities which teachers can implement in teaching and they are all aware if the importance of interaction for their language development.

Finally, classroom observations have provided some insight on practical application of interactive activities which teachers used to accomplish interaction in online classes. Some activities are used before during face=to=face teaching (Question and answer method, Review of the previous lesson and Brainstorming), but some of them are applicable mainly in online teaching (Discussion and analysis of the Online Video and Students' Online presentations). 


\section{CONCLUSION}

The focus of this paper was to find out and discuss interaction activities used in online setting during the COVID -19 Pandemic in North Macedonia. Also, an attempt was made to get some practical suggestions for increasing online interaction and finally, to see if the students are satisfied with the level of their interaction during different activities used by the teachers. The data collected from students' questionnaires, reflections and online observations reveled some useful results which can help teachers to increase students' interaction and engagement in their online classes.

Regarding the first research question: What are students' opinions about interaction during the online classes?, the findings obtained from questionnaire and reflections of the students, showed that students perceived interaction as a very important element of the qualitative teaching. They reported that they prefer to interact with their professors during English classes because it leads to better language learning. Additionally, they are externally motivated because interaction and class participation are part of their overall assessment. Most importantly, student hold positive attitude towards classroom interaction because it helps them to be better in learning a language and they were pleasantly satisfied with most of the professors' approaches regarding this matter as well as the professors' preparedness to teaching online. They suggested that the teachers should create a friendly atmosphere because it can help them to engage more. Similarly, in a study conducted by Mishra et.al $(2020$, p.6)" Students' perceptions reflected that teachers should create friend- ship and enlighten the environment of the groups".

Regarding the second research question: How are the students satisfied with the kind of activities the teacher varied during the online lessons and what do they prefer to have?, the collected data from student reflections shows that most of the students are satisfied with the online classes in particular with the level of engagement in interaction. This includes most of the professors who used different activities to engage students in different online activities. However, the students believe that the option "raise your hand" on Google classroom that they added recently is excellent for this reason but when no one raises the hand to participate in discussion, calling out students by their name will motivate them to follow the lesson actively and get rid of the fear to share their thoughts. They have also provided some practical suggestions for teachers and what they would prefer to have. These activities include: Asking questions during lectures $(7$ similar responses), Using a mix of learning tools, more visuals and audio and 
provide feedback (5 similar responses), Appointing the students to answer the questions not only on voluntary basis (4 similar responses), To leave the camera on because this should lead to a great interaction because every student would be obliged to interact instead of just joining the Google Meet (3 similar responses), Set up simple/appropriate case scenarios (encourages problem solving, critical thinking activities ( 3 similar responses), etc.

Regarding the third research question: " Which activities do the teachers use in order to accomplish interaction in online classes?, the data obtained from classroom observations showed that teachers in fact used different interaction activities at all stages of learning, at the beginning of the class, during the class and at the end of the class. The most-used interaction activity observed was the Question and answer Method as used by 4 lecturers. In most cases observed, the lecturers managed very well in an effective way built an admirable amount of interaction into the class, particularly given the constraints of the Google Meet. One lecturer also made efforts to call directly upon students who were being 'quiet' but this should be practiced more often by all lecturers who use this activity in the online class. Another element, which has changed from face-to-face learning into online learning conditions, was Discussion and analysis of the Online Video as used by 3 lecturers. The students were sent a link of the Video, they watched it during the class and then discussed at and analyzed it very well. The teachers acted mainly as a facilitator because students discussed it with their peers.

Also, students' presentations were something new because the teachers had to train the students first how to share the screen and present it online. The evaluation rubric was adapted to online learning as well. Perhaps, this was a good opportunity for the students who will become future teachers of English to see how are the online presentations done and be ready for the challenges that they might face in their future teaching career.

Based on the above-mentioned data the study recommends that all professors should use appropriate and varied online activities and tasks which can promote students' engagement in interaction and make the needed modifications to the course content and classroom activities. In order to ensure high level of interaction, teachers should include all students by calling out their names and keep them involved during the online classes. Due to poor internet connection, the professors should consider recording the meetings and send the link to the students so they can watch them whenever suitable for them. Perhaps the most important element to be considered is to provide continued training or 
seminars for professors where they can discuss the implementation of different interactive activities which can help in achieving high level of interaction in the online classes

\section{Works Cited:}

Aggarwal, A., \& Bento, R. (2000). Web-based education. In: A. Aggarwal (Ed.), Web-based learning and teaching technologies: Opportunities and challenges (pp. 59-77). Hershey: IDEA group publishing

Cavanaugh, C.et.al.(2009). Research Committee Issues Brief: Examining Communication and Interaction in Online Teaching. Retrieved on July 15, from the web: https://files.eric.ed.gov/fulltext/ED509630.pdf

Chickering, A. W., \& Gamson, Z. (1987). Seven principles for good practice in undergraduate education. Racine, WI.: The Johnson Foundation.

Croxton, R. A. (2014). The role of interactivity in student satisfaction and persistence in online learning. Merlot Journal of Online Learning and Teaching, 10(2), 314-325.

Downing, K. J. \& Chim, T. M. (2004a) What are the characteristics of effective online students?, paper presented at the Fifteenth International Conference on College Teaching and Learning, Jacksonville, FL, 29 March-2 April

Durrington, V. A., Berryhill, A., \& Swafford, J. (2006). Strategies for Enhancing Student Interactivity in an Online Environment. College Teaching. https://doi.org/10.3200/ctch.54.1.190-193

Grandzol, Christian J. and Grandzol, John R. (2010). Interaction in Online Courses: More is NOT Always Better. Online Journal of Distance Learning Administration, Vol. 13, N.2

Kaymak, Demir, Horzum, Zeliha and Baris, Mehmet (2013). Relationship between Online Learning Readiness and Structure and Interaction of Online Learning Students. In: Educational Sciences: Theory and Practice, Vol.13, N.3. Retrieved on May 1, from the web:

https://eric.ed.gov/?id=EJ1017736

Krashen, Stephen D. (1988). Second Language Acquisition and Second Language Learning. Prentice-Hall International

Krishnamurthi, M. (2000, June), Enhancing Student Teacher Interaction In Internet Based Courses Paper presented at 2000 Annual Conference, St. Louis, Missouri. 10.18260/1-2--8359

Mishra, L., Gupta, T. and Shree, A. (2020). Online teaching-learning in higher education during lockdown period of COVID-19 pandemic. In: International Journal of Educational Research.

https://doi.org/10.1016/i.ijedro.2020.100012

Moore, M. G. (1989). Three types of interaction, American Journal of Distance Education, 3(2), 1-6.

Huang, Qiang (2018). Examining Teachers' Roles in Online Learning. The EUROCALL Review, Volume 26, No. 2. Retrieved on April 21, from the web: 
https://www.researchgate.net/publication/333064935 Examining Teac hers\%27 Roles in Online Learning

Pauls, T. S. (2003). The importance of interaction in online courses. Ohio Learning Network. Windows on the future 2003. Retrieved May 5, 2021 from the web:

http://www.oln.org/conferences/OLN2003/OLN2003papers.php.

Travis, Jon E. and Rutherford, Grace (2012-2013). Administrative support of Faculty preparation and interactive online teaching: Factors in student success. In: National forum of educational administration and supervision Journal, Vol.30, N.1

Xhaferi, B. and Xhaferi , G. (2020). Online learning benefits and challenges during the Covid 19-Pandemic - Students' perspectives from SEEU . In SEEU REVIEW , pp. 86-103. South East European University, Tetove , ISBN Vol.15, Issue 1.

Zhang, Yining and Lin, Chin-His (2019). Student interaction and the role of the teacher in a state virtual high school: what predicts online learning satisfaction?. Retvied on March 2021, from the web: https://www.tandfonline.com/doi/abs/10.1080/1475939X.2019.169406 1?journalCode=rtpe20

\section{INTERAKTION DER STUDIERENDEN IM ONLINE-UNTERRICHT WÄHREND DER COVID-19-PANDEMIE IN NORDMAZEDONIEN}

Das Ziel dieser Studie ist es, die durchgeführten Interaktionsaktivitäten von Studierenden in Zeiten der COVID-19-Pandemie im Online-Lehre zu analysieren. Der Begriff Interaktion ist im Bereich des Zweitspracherwerbs weitgehend anerkannt im Sinne der Interaktionshypothese von Long (1985), die belegt, dass die Sprachkompetenz stark erhöht wird, wenn es im Fremdsprachenunterricht eine Interaktion im Klassenzimmer gibt. Für die Interaktion im Onlineunterricht müssen die Lehrenden eine hohe Interaktivität der Studierenden fördern und eine unterstützende und freundliche Umgebung schaffen. Der erste Schritt dazu wäre die Bereitstellung eines Lehrplans, der die Erwartungen des Kurses im Allgemeinen klar und einfach beschreibt und spezifische Richtlinien für jede Aufgabe, Anweisungen und Fristen festhält (Durrington et al., 2006).

Infolgedessen bleibt dieses Thema eine Herausforderung für die Lehrkräfte, von denen erwartet wird, dass sie ihren Präsenzunterricht in eine Onlineplattform umstellen, damit eine Interaktion der Studierenden als zentrales Element im Unterricht beibehalten wird. Selbstverständlich erfordert diese Aufgabe zusätzliche Zeit, Vorbereitung und technische Unterstützung. Eine angemessene Personalentwicklung und die Motivation der Studierenden sind entscheidend, um sicherzustellen, dass die Fakultät effektive Onlinekurse gestalten und die Fähigkeit zur Verbesserung der Interaktion zwischen den Studierenden entwickeln kann. 
Für diese Studie wurden Fragebögen für die Studierenden, Studentenreflexionen im Klassenzimmer und Beobachtungen der Online-Lehre verwendet. Die Studie wurde an der South East European University (SEEU) in Nordmazedonien mit Beteiligung von 80 Studierenden des Hauptfaches Englische Sprache und Literatur und fünf EFL-Lehrenden durchgeführt.

Die Ergebnisse der Studie zeigen, dass die befragten Studierenden die Interaktion als ein sehr wichtiges Element des qualitativen Unterrichts wahrnehmen und den Lehrenden nützliche Anregungen gegeben haben, ihr Engagement in Interaktionsaktivitäten zu erhöhen. Angesichts der Einschränkungen im Online-Unterricht wurde in allen beobachteten OnlineKlassen eine beispielhafte Interaktion durch Frage-und-Antwort-Methode, Verständnistechnik und Diskussion und Analyse von Online-Videos erreicht, wobei die Studierenden sowohl mit den Lehrenden als auch ihren Mitstudierenden interagierten.

Schlüsselwörter: Online-Lehre, Interaktion, Universitätsstudierende, COVID-19 Pandemie 